\title{
PERAN GURU DALAM MENERAPKAN PEMBELAJARAN MATEMATIKA YANG MENYENANGKAN BAGI ANAK USIA DINI
}

\author{
Dina Kusuma Wardhani \\ Program Studi PG PAUD FKIP Universitas Sultan Ageng Tirtayasa, Serang Banten \\ Email : dinakusuma_wardhani@yahoo.com
}

(Received: September 2017; Accepted: Oktober 2017; Published: Desember 2017)

\begin{abstract}
Introducing and teaching math to early childhood are suggested to be able to understand the child's development area because it can be applied the appropriate concepts and constraints in accordance with the child's ability so that the child's feel comfortable with the material conveyed. If child's development can be understood then the correct mathematical concepts it can be given to the child's, avoid mathematical fears, help the child's learn mathematics naturally through playing activity. Math games are given gradually; start with counting objects, experiences of concrete events experienced through observation of the natural surroundings, knowledge and skills in the game of mathematics. It can be given gradually according to the level of difficulty, for example from concrete to abstract, easy to difficult and simple to complex. The mathematical game will work if children are given the opportunity to participate and be stimulated to solve their own problems.
\end{abstract}

Keywords: child development area, mathematical concepts, principles from easy to difficult and from simple to complex

\begin{abstract}
ABSTRAK
Ketika berniat mengenalkan dan mengajarkan matematika kepada anak usia dini disarankan untuk dapat memahami area perkembangan anak karena melalui pijakan tersebut kita dapat menerapkan konsep dan batasan yang tepat sesuai dengan kemampuan anak sehingga anak merasa nyaman dan tidak bingung dengan materi yang kita sampaikan. Bila kita dapat memahami area perkembangan anak maka kita dapat memberikan materi kepada anak-anak berdasarkan konsep matematika yang benar, menghindari ketakutan matematika sejak awal, membantu anak belajar matematika secara alami melalui kegiatan bermain, Permainan matematika diberikan secara bertahap diawali dengan menghitung benda-benda atau pengalaman peristiwa kongkrit yang dialami melalui pengamatan terhadap alam sekitar, pengetahuan dan keterampilan pada permainan matematika diberikan secara bertahap menurut tingkat kesukarannya, misalnya dari konkret ke abstrak, mudah ke sukar dan dari sederhana ke yang lebih kompleks. Permainan matematika akan berhasil jika anak-anak diberi kesempatan berpartisipasi dan dirangsang untuk menyelesaikan masalah-masalahnya sendiri.
\end{abstract}

Kata Kunci : Area Perkembangan Anak, Konsep Matematika, Prinsip dari Mudah ke Sukar dan Dari Sederhana ke yang Lebih Kompleks.

\section{PENDAHULUAN}

\section{Latar Belakang}

Matematika adalah mata pelajaran yang penting. Matematika juga termasuk mata pelajaran yang menjadi standar untuk diujikan ketika akan melanjutkan ke jenjang pendidikan yang lebih tinggi. Sementara itu, bagi kebanyakan orang ternyata matematika sering kali dianggap sebagai pelajaran yang sulit bahkan menakutkan lalu bagaimana anak-anak kecil bisa diajarkan matematika sejak dini, apakah mereka tidak akan merasa kesulitan sehingga mereka malah frustasi sejak dini terhadap matematika.
Materi dan konsep matematika yang diajarkan harus disesuaikan dengan kemampuan dan tahap berfikir anak yang bersangkutan. Membangun rasa ingin tahu anak secara alami tentangbentuk, ukuran, jumlah,konsep-konsep dasar lain dalam matematika, Peduli dan tertarik terhadapa apa yang dikatakan anak. Hal ini akan mendorong anak untuk menceritakan pengalaman dan penemuan mereka. Penerimaan terhadap sejumlah kegiatan matematika yang dilakukan anak. Hal ini akan mendorong kepercayaan diri untuk tetap berfikir, bertanya dan berbagi 
pengalaman tentang berbagai hal yang dialami anak

\section{Rumusan Masalah}

a. Apa hakikat matematika ?

b. Bagaimanapengaruh permainan matematika bagi kehidupan anak ?

c. Bagaimana kegiatan belajar dalam permainan matematika?

\section{Tujuan}

a. Dapat mengetahui hakikat matematika

b. Dapat mengetahui pengaruh permainan matematika bagi AUD

c. Dapat mengetahui kegiatan belajar dalam permainan matematika

\section{KAJIAN PUSTAKA}

\section{Hakikat Matematika}

Dari berbagai pendapat tentang hakikat matematika yang telah dikemukakan dapat disimpulkan bahwa matematika sebagai ilmu tentang kuantitas (the science of quantity) atau ilmu tentang ukuran diskrit dan berlanjut (the science of discrate and continuous).

Ketika berniat mengenalkan dan mengajarkan matematika kepada anak yang masih sangat kecil disarankan untuk dapat memahami sedikit penjelasan dari para ahli tersebut. Mengingat para ahli sendiri belum ada yang sepakat mengenai hakikat matematika untuk PAUD, maka dengan berpijak pada pengertian para ahli tersebut, hal itu bisa dijelaskan sesuai dengan yang dipahami dan tidak membingungkan anak serta tidak keluar dari konteks matematika.

\section{Landasan Pengenalan Matematika Anak Usia Dini}

Beberapa teori yang mendasari perlunya permainan matematika anak usia dini adalah sebagai berikut :

1) Tingkat perkembangan mental anak

Jean piaget, menyatakan bahwa kegiatan belajar memerlukan kesiapan dalam diri anak. Artinya belajar sebagai suatu proses membutuhkan aktifitas baik fisik maupun psikis. Selain itu kegiatan belajar pada anak harus disesuaikan dengan tahap-tahap perkembangan mental anak, karena belajar bagi anak harus keluar dari anak itu sendiri.

2) Masa peka berhitung pada anak

Perkembangan dipengaruhi oleh faktor kematangan dan belajar. Apabila anak sudah menunjukan masa peka (kematangan) untuk berhitung, maka orangtua dan guru di TK harus tanggap, untuk segera memberikan layanan dan bimbingan sehingga kebutuhan anak daya terpenuhi dan tersalurkan dengan sebaik-baiknya menuju perkembangan kemampuan berhitung yang optimal.

Anak usia TK adalah masa yang strategis untuk mengenalkan berhitung di jalur matematika, karena usia TK sangat peka terhadap rangsangan yang diterima dari lingkungan. Rasa ingin tahunya yang tinggi akan tersalurkan apabila mendapat stimulasi atau rangsangan serta motivasi yang sesuai dengan tugas perkembangannya. Apabila kegiatan berhitung diberikan melalui berbagai macam permainan tentunya akan lebih efektif karena bermain merupakan wahana belajar dan bekerja bagi anak.diyakini bahwa anak akan lebih berhasil mempelajari sesuatu apabila yang ia pelajari sesuai dengan minat, kebutuhan dan kemampuannya.

Berdasarkan hasil penelitian yang dilakukan oleh Orborn (1981) perkembangan intelektual pada anak berkembang sangat pesat pada kurun usia 0 hingga usia pra sekolah (4-6 tahun). Oleh sebab itu, usia pra sekolah seringkali disebut sebagai "masa peka belajar". Pernayataan didukung oleh Benyamin S.Bloom yang menyatakan bahwa $50 \%$ dari potensi intelektual anak sudah terbentuk usia 4 tahun kemudian mencapai sekitar $80 \%$ pada usia 8 tahun.

3) Perkembangan awal menentukan perkembangan selanjutnya

Hurlock (1993) mengatakan bahwa lima tahun pertama dalam kehidupan anak merupakan peletak dasara bagi perkembangan selanjutnya.anak yang mengalami masa bahagia berarti terepenuhinya segala kebutuhan baik fisik maupun psikis di awal perkembangannya diramalkan akan dapat melaksanakan tugas-tugas perkembangan selanjutnya. Piaget juga mengatakan bahwa 
untuk meningkatkan perkembangan mental anak tahap yang lebih tinggi dapat dilakukan dengan memperkaya pengalaman anak terutama pengalaman kongkrit, karena dasar perkembangan mental adalah melalui pengalaman-pengalaman aktif dengan menggunakan benda-benda disekitarnya. Pendidikan di TK sangat penting untuk mencapai keberhasilan belajar pada tingkat pendiidkan selanjutnya. Bloom bahkan menyatakan bahwa mempelajari bagaimana belajar (learning to learn) yang terbentuk pada masa pendidikan TK akan tumbuh menjadi kebiasaan di tingkat pendidikan selanjutnya.hal ini bukanlah sekedar proses pelatihan agar anak mampu membaca, menulis dan berhitung,tetapi merupakan cara belajar belajar mendasar ,yang meliputi kegiatan yang dapat memotivasi anak untuk menemukan kesenangan dalam belajar, mengembangkan konsep diri (perasaan mampu dan percaya diri), melatih kedisplinan, percaya diri dan tanggung jawab.

Sejalan dengan beberapa teori yang dikemukakan diatas, permainan matematika anak usia dini seyogyanya dilakukan melalui tiga tahapan penguasaan berhitung di jalur matematika :

\section{a) Penguasaan konsep}

Pemahaman atau pengertian tentang sesuatu dengan menggunakan benda dan peristiwa konkret, seperti pengenalan warna, bentuk dan menghitung benda atau bilangan.

b) Masa transisi

Proses berpikir yang merupakan masa peralihan dari pemahaman kongkrit menuju pengenalan lambing yang abstrak,dimana benda kongkrit itu masih ada dan mulai dikenalkan bentuk lambangnya.

c) Lambang

Merupakan visualisasi dari berbagai konsep. Misalnya lambang 7 untuk menggambarkan konsep bilangan tujuh, merah untuk menggambrkan konsep warna, besar untuk menggambarkan konsep ruang, dan sebagainya.

\section{Perkembangan Matematika di PAUD}

Kemampuan anak-anak untuk memahami matematika mengalami perkembangan yang cukup pesat mulai usia pra sekolah. Pada permulaan tahun ke3 usianya, anak-anak sudah bisa menggunakan jari-jarinya untuk menunjukan banyak benda. Mungkin saja pada saat itu anak melakukan kesalahan dengan perhitungannya, tetapi itu merupakan sebuah perilaku matematika (mathematical behavior) yang ditunjukannya.

Pada usia 4 tahun,anak-anak sudah mulai bisa menghitung.biasanya mereka sudah bisa menghitung 1-5 atau 1-10, dan sudah bisa menyebutkan bilangan berikutnya dari sebuah barisan bilangan. Misalnya, ibu guru mengitung 12345 kemudian guru bertanya bilangan berapa berikutnya, maka si anak akan menjawab Dalam geometri, anak-anak sudah dapat mengenali, mengelompokkan dan menyebutkan nama-nama bentuk bangun,baik bangun datar ataupun bangun ruang yang bermacam-macam ukuran dan bentuknya.anak juga belajar menggunakan kata-kata penunjuk seperti atas, bawah, kiri, kanan, tengah dan lain sebagainya. Pada usia 4 atau 5 tahun, anak sudah bisa menggunakan kata-kata itu dalam bentuk kalimat untuk menggambarkan letak atau posisi tertentu.

Pemahaman konsep mengukur mengalami lonjakan ketika anak-anak mulai bisa membandingkan ukuran sebuah objek.pada usia 3 tahun, anak-anak sudah bisa menunjukan siapa yang lebih tinggi.sementara pada usia 4 tahun, dia sudah mulai bisa melakukan proses yang lebih kompleks lagi dalam membandingkan beberapa ukuran.

\section{Keterampilan yang Dibutuhkan dalam permainan matematika}

Ada beberapa hal yang perlu diperhatikan agar pembelajaran matematika itu berlangsung efektif dan berhasil dengan baik seperti apa yang diharapkan. Berikut adalah tips agar pembelajaran matematika bersama anak berhasil dengan baik :

\section{1) Lakukan pengulangan}

Pengulangan bisa berfungsi sebagai pemuatan sehingga konsep lebih tertanam di otak anak. Sering-seringlah melakukan 
pengulangan terhadap konsep matematika yang telah diajarkan.

2) Lingkungan yang kondusif

Anak tidak akan pernah bisa berkembang optimal dalam hal apapun jika tidak ada lingkungan kondusif yang menunjangnya. Membantu menumbuhkan semangat belajar,penghargaan dan penguasaan matematika pada anak-anak adalah sangat penting, sebab perkembangan ilmu pengetahuan dan teknologi di dunia saat ini,membutuhkan kemampuan matematika cukup kuat.

3) Buat menyenangkan

Belajar apapun akan sangat efektif jika pembelajarannya menyenangkan Maka, agar pembelajaran matematika berhasil efektif.

4) Gunakan beragam media

Belajar itu tidak harus berhadapan dengan buku dan alat tulis,guru sesekali menontonkan video edukatif kepada anak sesuai pembelajarannya.

\section{Prinsip-prinsip}

\section{Permainan}

\section{Matematika Anak Usia Dini}

a) Permainan matematika diberikan secara bertahap diawali dengan menghitung benda-benda atau pengalaman peristiwa kongkrit yang dialami melalui pengamatan terhadap alam sekitar.

b) Pengetahuan dan keterampilan pada permainan matematika diberikan secara bertahap menurut tingkat kesukarannya, misalnya dari konkret ke abstrak, mudah ke sukar, dan dari sederhana ke yang lebih kompleks.

c) Permainan matematika akan berhasil jika anak-anak diberi kesempatan berpartisipasi dan dirangsang untuk menyelesaikan masalah-masalahnya sendiri.

d) Permainan matematika membutuhkan suasana yang menyenangkan dan rasa aman serta kebebasan bagi anak.untuk itu diperlukan alat peraga/media yang sesuai dengan tujuan, menarik, dan bervariasi, mudah digunakan dan tidak membahayakan. e) Bahasa yanag digunakan didalam pengenalan konsep berhitung seyogyanya bahasa yang sederhana dan jika memungkinkan mengambil contoh yang terdapat lingkungan sekitar anak.

f) Dalam permainan matematika anak dapat dikelompokkan sesuai tahap penguasaan berhitung yaitu tahap konsep, masa transisi dan lambing.

g) Dalam mengevaluasi hasil perkembangan anak harus dimulai dari awal sampai akahir kegiatan.

\section{Manfaat Permainan Matematika untuk AUD}

1. Membelajarkan anak-anak berdasarkan konsep matematika yang benar

2. Menghindari ketakutan matematika sejak awal

3. Membantu anak belajar matematika secara alami melalui kegiatan bermain

\section{Peran Guru dalam Mengembangkan} Kegiatan Belajar Matematika

a) Membangun rasa ingin tahu anak secara alami tentang bentuk, ukuran, jumlah, konsep-konsep dasar lain dalam matematika

b) Peduli dan tertarik terhadapa apa yang dikatakan anak. Hal ini akan mendorong anak untuk menceritakan pengalaman dan penemuan mereka

c) Penerimaan terehadap sejumlah kegiatan matematika yang dilakukan anak. Hal ini akan mendorong kepercayaan diri un tuk tetap berfikir,bertanya,dan berbagi pengalaman tentang berbagai hal yang dialami anak

8. Ciri-ciri yang Menandai bahwa Anak Sudah Mulai Menyenangi Permainan Berhitung

a) Secara spontan telah menunjukan ketertarikan pada aktivitas permainan berhitung

b) Anak mulai menyebut urutan bilangan tanpa pemahaman

c) Anak mulai mengitung benda-benda yang ada disekitarnya secaraa spontan 
d) Anak mulai membanding-bandingkan benda-benda dan peristiwa yang ada disekitarnya

e) Anak mulai menjumlah-jumlahkan atau mengurangi angka dan benda-benda yang ada disekitarnya tanpa disengaja.

\section{Hal yang Perlu Diperhatikan}

a) Apabila anak yang cepat menyelesaikan tugas yang diberikan guru,hal ini menunjukan bahwa anak tersebut telah siap untuk diebrikan permainan berhitung dengan tingkat kesulitan yang lebih tinggi

b) Apabila anak menunjukan tingkah laku jenuh, diam, acuh tak acuh atau mengalihkan perhatian pada hal lain, hal ini menunjukan bahwa telah menjadi masalah pada anak .itu berarti ,anak membutuhkan perhatian atau perlakuan yang lebih khusus dari guru.

\section{Standar Matematika untuk Anak Usia Dini}

The principles and standards for school mathematics (prinsip dan standar untuk matematika sekolah), yang dikembangkan oleh pendidik dari National council of teacher of mathematics (Nctm, 2000) memaparkan harapan matematika untuk anak usia dini, konsep-konsep yang bisa dipahami anak usia dini antara lain :

\section{1) Bilangan}

Salah satu konsep matematika yang paling penting dipelajari anak adalah pengembangan kepekaaan bilangan.peka terhadap bilangan berarti tidak sekedar menghitung. Kepekaan bilangan itu mencakup pengembangan rasa kuantitas dan pemahaman kesesuaian satu lawan satu.ketika kepekaan terhadap bilangan anak-anak berkembang ,mereka menjadi semakin tertarik pada hitung menghitung. Menghitung ini menjadi landasan bagi pekerjaan dini anak-anak dalm bilangan.

2) Aljabar

Menurut NTCM (2000), pengenalan aljabar dimulai dengan menyortir, menggolongkan, membandingkan, dan menyusun benda-benda menurut bentuk, jumlah, dan sifat-sifat lain, mengenal, menggambarkan, dan memperluas pola akan memberi sumbangan kepada pengembangan anak tentang penggolongan.

\section{3) Penggolongan}

Penggolongan (klasifikasi) adalah
suatu proses yang penting untuk mengembangkan konsep bilangan.supaya anak mampu menggolongkan atau menyortir bendabenda,mereka harus mengembangkan pengertian tentang "saling memiliki kesamaan", "keserupaan", "kesamaan", dan "perbedaan". Kegiatan yang dapat mendukung kemampuan klasifikasi anak adalah :

a) Membandingkan

Proses dimana membangun suatu hubungan dengan antara dua benda berdasarkan atribut tertentu.anak usia dini sering membuat perbedaan ,terutama bila perbandingan itu melibatkan mereka secara pribadi.

b) Menyusun

Menyusun atau menata adalah tingkat lebih tinggi dari perbandingan.menyusun melibatkan perbandingan benda-benda yang lebih banyak,menempatkan benda-benda dalam satu urutan .kegiatan menyusun dapat dilakukan didalam dan diluar kelas,misalnya menyusun buku yang diatur dari yang paling tebal,mengaatur barisan dari anak-anak yang paling tinggi atau pen dek, dan lain-lain.

c) Pola-pola

Mengidentifikasi dan menciptakan pola dihubungkan dengan penggolongan dan penyortiran. Anak-anak senang membuat pola dilingkungan mereka.

d) Geometri

Membangun konsep geometri pada anak dimulai dengan mengidentifikasi bentukbentuk,menyelidiki bangunan dan memisahkan gambar-gambar biasa seperti segiempat, segitiga.

e) Pengukuran

Ketika anak mempunyai kesempatan untuk pengalaman-pengalaman langsung untuk mengukur, menimbang, dan membandingkan ukuran benda-benda,mereka belajar konsep pengukuran.

f) Analisis data dan probabilitas 
Percobaan dengan pengukuran, penggolongan dan penyortiran merupakan dasar untuk memahami probabilitas dan analisis data ini bearti mengemukakan, mengumpulkan informasi tentang dirinya dan lingkungan mereka, dan menyampaikan informasi ini secara hidup.

\section{Permainan Berhitung Dijalur Matematika}

1. Bermain pola

Anak diharapkan mengenal dan menyusun pola-pola yang terdapat disekitarnya secara berurutan,setelah melihat 2 atau 3 pola yang ditujukan oleh guru anak mampu nmembuat urutan pola sendiri sesuai dengan kreatifitasnya.

2. Bermain klasifikasi

Anak diharapkan dapat mengelompokan atau memilih benda berdasarkan jenis,fungsi, warna,bentuk pasangannya sesuai dengan contoh yang ditentukan dan tugas yang diberikan guru.

\section{Bermain bilangan}

Anak diharapkan mampu mengenal dan memahami konsep bilangan,transisi dan lambang sesuai dengan jumlah benda-benda pengenalan bentuk lambang dan dapat mencocokan sesuai dengan lambang bilangan.

4. Bermain ukuran

Anak diharapkan dapat mengenal konsep ukuran standar yang bersifat informal atau alamiah, seperti panjang, besar, tinggi, dan isi melalui alat ukur ilmiah, antara lain jengkal, jari, langkah, tali, lidi, dan lain-lain.

\section{Bermain geometri}

Anak diharapkan dapat mengenal dan menyebutkan berbagai macam benda, berdasarkan bentuk geometri dengan cara mengamati benda-benda yang disekitarnya.

6. Bermain estimasi (memperkirakan)

Anak diharapkan dapat memliki kemampuan memperkirakan sesuatu misalnya perkiraan terhadap waktu,luas jumlah ataupun ruang.selain itu anak terlatih untuk mengantisipasi berbagai kemungkinan yang akan dihadapi.
Anak diharapkan dapat memiliki kemampuan untuk memahami perbedaanperbedaan dalam jumlah dan perbandingan dari hasil pengamatan terhadap suatu objek (dalam bentuk visual).

\section{Metode Permainan Berhitung}

1) Metode bercerita

Adalah cara bertutur kata dan menyampaikan cerita atau memberikan penerangan kepada anak secara lisan,jenisnya antara lain ,bercerita dengan alat peraga,tanpa alat peraga,dengan gambar,dan lain-lain.

2) Metode bercakap-cakap

Adalah salah satu penyampaian bahan pengembangan yang dilaksanakan melalui bercaka-cakap dalam bentuk tanya jawab antara anak dengan guru, atau anak dengan anak.

3) Metode tanya jawab

Dilaksanakan dengan memberikan pertanyaaan -pertanyaan yang dapat memberikan rangsangan agar anak aktif untuk berpikir melalui pertanyaan guru anak akan berusaha untuk memahaminya dan menemukan jawabannya .

4) Metode pemberian tugas

Adalah pemberian kegiatan belajarmengajar dengan memberikan kesempatan kepada anak untuk melaksanakan tugas yang disediakan guru .

5) Metode demonstrasi

Adalah suatu cara untuk mempertunjukan atau memperagakan suatu objek atau proses dari suatu kegiatan atau peristiwa.

6) Metode eksperimen

Adalah metodekegiatan dengan melakukan sesuatu percobaan dnegan cara mengamati proses dan hasil dari percobaan tersebut.

Pemanfaatan media untuk pengenalan matematika anak usia dini 


\section{Media yang dapat digunakan untuk pembelajaran matematika anak usia dini}

1) Media visual Media yang hanya dapat dilihat.medianya gambar, kartu angka, benda 3 dimensi, benda nyata, dan lain-lainMedia audio

Media yang mengandung pesan dalam bentuk auditif (hanya dapat didengar) yang dapat merangsang pikiran, persaan, dan kemauan anak untuk mempelajari isi tema, misalnya kaset lagu anak-anak.

2) Media audio visual

Alat-alat yang audible artinya dapat didengar dan yang fisible artinya dapat dilihat misalnya televise, $\mathrm{CD}$ pembelajaran matematika, dan lain-lain.

3) Lingkungan sekitar

Lingkungan sekitar dapat dimanfaatkan untuk pengenalan matematika anak usia dini,bahkan dnegan pemanfaatan lingkungan sekitar ini akan medorong anak untuk memahami konsep matematika secara alamiah, contoh kegiatannya bereksperimen, bereksplorasi, dan lain-lain.

\section{KESIMPULAN DAN SARAN}

Matematika adalah bahasa symbol. Sebuah bahasa universal yang bisa di pahami tanpa makna ganda sehingga menghilangkan sifat kabur, majemuk, dan emosional. Mengenalkan matematika kepada anak diharuskan sesuai dengan cara berpikir anak tersebut, supaya bisa dipahami dan tidak membingungkan anak, tetapi tidak sampai keluar dari konteks matematika itu sendiri.

Supaya anak tidak mengalami kesulitan dalam belajar matematika, banyak yang diperlukan oleh seorang guru, namun yang paling utama adalah keterampilan. Keterampilan sangat penting untuk dimiliki oleh seorang guru khususnya guru PAUD. Dalam mengajarkan matematika juga dibutuhkan keterampilan khusus, supaya anak bisa memahami dasar-dasar dari matematika itu sendiri. Misalnya mengenalkan angka dari 1-10 itu pun tidak bisa langsung di kenalkan kepada AUD, harus dilakukan dengan sambil menyanyi atau ada bantuan alat peraga sehingga anak tersebut bisa memahami dan tidak cepat bosan.

\section{DAFTAR PUSTAKA}

Beaty Janice J, 2013, Observasi Perkembangan Anak Usia Dini Edisi Ketuju, Surabaya : Cropp Media.

Ismayani Ani, 2010, Fun Math With Children, Jakarta : Elex Media Komputindo

Santoso, AM Rukky, 2001, Mengembangkan Otak Kanan Anak-anak, Jakarta : Gramedia Pustaka Utama

Surna I nyoman. - D.pendeirot,olga. 2014. Pisikologi Pendidikan 1. Jakarta: Erlangga

Yahya Corbudin, 2008, Belajar Matematika bagi Anak, Jakarta: BPK. 